\title{
Stacked traits conferring multiple resistance to imazamox and glufosinate in soft wheat
}

\author{
Rafael Domínguez-Mendez, ${ }^{\mathrm{a}}$ Ricardo Alcántara-de la Cruz,, ${ }^{\text {b* }}$ \\ Antonia M Rojano-Delgado, ${ }^{a}$ Hellen Martins da Silveira,' João Portugal,d \\ Hugo Enrique Cruz-Hipolito ${ }^{e}$ and Rafael De Prado ${ }^{a}$
}

\section{Abstract}

BACKGROUND: Conventional crossing of soft wheat cultivars resistant to imazamox and glufosinate resulted in two (Rados and Helter) lines resistant to both herbicides. Stacked traits conferring this dual herbicide resistance in these lines, compared with a susceptible (S) cultivar, were characterized.

RESULTS: Rados and Helter lines were 18-fold more resistant (R) to glufosinate, and between 15.1 and 19.8 -fold more resistant to imazamox than the S cultivar. Resistance to glufosinate and imazamox decreased up to $12 \%$ and $50 \%$, respectively, when the herbicides were applied sequentially. The basal activities of the acetolactate and glutamine synthases were similar between $R$ and S plants. Rados and Helter lines were 11.7- and 17.7-fold more resistant to imazamox than the $S$ cultivar, due to the Ser653-Asn mutation in their imi-ALS genes. $R$ lines, susceptible to glufosinate at the target site level, showed lower ammonia accumulation evidencing the activity of the phosphinothricin acetyl transferase. Absorption and translocation patterns for ${ }^{14} \mathrm{C}$-imazamox and ${ }^{14} \mathrm{C}$-glufosinate were similar between $\mathrm{R}$ and $\mathrm{S}$ cultivars and so do not contribute to resistance.

CONCLUSION: Stacked traits conferring dual herbicide resistance to the lines Rados and Helter come from the resistant parents. These $\mathbf{R}$ lines are potential tools for weed management in wheat production, mainly via herbicide rotation. (C) 2018 Society of Chemical Industry

Supporting information may be found in the online version of this article.

Keywords: acetolactate synthase; glutamine synthase; herbicide resistance crops; $\mathrm{N}$-acetyl-glufosinate; phosphinothricin acetyl transferase; Triticum aestivum

\section{INTRODUCTION}

Wheat (Triticum spp.) is a crop of great economic importance with current production estimated at $>720$ million tons per year worldwide, ${ }^{1}$ used for the production of human and animal food. Weeds are major biotic factors in crop production, competing for soil, water, light and nutrients. ${ }^{2}$ In wheat, weeds can result in a reduction in yield of up to $50 \%$. $^{3}$

Plant transformation methods (biolistic, electroporation, microinjection, Agrobacterium tumefaciens-mediated cell transformation, etc.), conventional plant breeding (plant selection, outcrossing with elite cultivars, mutagenesis, etc.), and combinations thereof have delivered herbicide-resistant (HR) crops that offer significant advantages for weed control. ${ }^{4,5}$ These crops were introduced in the mid-1990s and adopted quickly by farmers. However, the use of HR crops resistant to a single mode of action and their improper use has led to the rapid expansion of a wide range of HR weeds, decreasing the value of this technology. ${ }^{6}$ Judicious adoption of HR crops and their associated agronomic practices may help to maintain the biodiversity of agricultural lands and reduce the risk of weeds evolving herbicide resistance. ${ }^{7}$ To improve this technology, HR crops with multiple or stacked traits are being developed. ${ }^{8,9}$ Meanwhile, efforts are being made to implement new weed management strategies. ${ }^{10}$
Imazamox and ammonium glufosinate (glufosinate) are two of the most effective post-emergence herbicides. Imazamox is a systemic broad-spectrum herbicide that inhibits the enzyme acetolactate synthase (ALS), disrupting the synthesis of valine, leucine and isoleucine. ${ }^{11}$ Glufosinate is a contact and non-selective herbicide that is minimally translocated, requiring complete coverage to ensure weed control. ${ }^{12}$ This herbicide inhibits the activity of glutamine synthase (GS; EC 6.3.1.2), causing rapid accumulation of

\footnotetext{
* Correspondence to: $R$ Alcántara-de la Cruz, Departamento de Entomologia/BIOAGRO, Universidade Federal de Viçosa, 36570-900 Viçosa, Brazil. E-mail: ricardo.la@ufv.br

a Department of Agricultural Chemistry and Edaphology, University of Cordoba, Cordoba, Spain

b Departamento de Entomologia/BIOAGRO, Universidade Federal de Viçosa, Viçosa, Brazil

c Departamento de Fitotecnia, Universidade Federal de Viçosa, Viçosa, Brazil

d Department of Biosciences, Research Centerfor Endogenous Resource Valorization's, Polytechnic Institute of Beja, Beja, Portugal

e Bayer CropScience Mexico, Mexico City, Mexico
} 
ammonia within the plant and damaging chloroplast and photosynthesis structures. ${ }^{13}$

Crop varieties resistant to imidazolinone herbicides (ALS inhibitors group) are based on non-transgenic Clearfield technology developed by BASF. Its resistance is attributed to the Ser653-Asn mutation in ALS homologous genes located in chromosomes $6 \mathrm{~B}$ and $6 \mathrm{D}$ of wheat. ${ }^{14-16}$ Glufosinate resistance in crops is due to the bar (bialaphos resistance) or pat (phosphinothricin $\mathrm{N}$-acetyltransferase) genes, isolated from Streptomyces viridochromogenes and S. hygroscopicus, respectively. These genes are $87 \%$ identical at the nucleotide sequence level, and both encode phosphinothricin acetyl transferase (PAT; EC 2.3.1.183), ${ }^{13}$ responsible for deactivating the glufosinate to $\mathrm{N}$-acetyl-glufosinate. ${ }^{17} \mathrm{How}$ ever, other resistance mechanisms should not be ruled out, such as foliar morphological alterations related to herbicide retention, decreased absorption and translocation, and detoxification of the herbicide by the plant. ${ }^{11}$

Crossing soft wheat (Triticum aestivum L.) cultivars resistant to imazamox and glufosinate using conventional methods resulted in lines resistant to both herbicides. The objectives of this study were: (i) to evaluate the degree of resistance to imazamox and glufosinate in two new resistant soft wheat varieties compared with a susceptible wheat cultivar, and (ii) to determine if resistance was accounted for entirely by the predicted stacked traits.

\section{MATERIAL AND METHODS}

\subsection{Plant material, experimental conditions and herbicide treatments}

The HR wheat lines Rados and Helter, each with multiple resistance to imazamox and glufosinate (IMA + GLU), came from crossing the glufosinate-resistant T-590 line (IAS/CSIC-Cordoba, Spain) with the Clearfield ${ }^{\circledR}$ Pantera cultivar resistant to imazamox (INIA-Carillanca, Chile). The Pantera cultivar has the Ser653-Asn mutation in the ALS-imi1 and ALS-imi2 genes. ${ }^{15}$ The T-590 line contains the bar gene from $\mathrm{pACH} 25$ plasmid, which encodes the PAT enzyme. ${ }^{18}$

Seeds from the $\mathrm{T}-590 \times$ Pantera cross $\left(\mathrm{F}_{1}\right.$ progeny) were sown in $15-\mathrm{cm}$ Petri dishes containing two layers of filter paper moistened with $10 \mathrm{~mL}$ of distilled water and sealed with Parafilm. Seeds were maintained until germination in a growth chamber at $26 / 16^{\circ} \mathrm{C}$ (day/night), a $14 / 10 \mathrm{~h}$ photoperiod, a light density of $850 \mathrm{mmol} \mathrm{m}^{-2} \mathrm{~s}^{-1}$, and $60 \%$ relative humidity $(\mathrm{RH})$. Seedlings were transplanted into $250-\mathrm{mL}$ pots (one plant per pot) containing a mixture of peat and sand (1:1), and kept in a growth chamber under the same conditions.

Fifty wheat plants with three to four true leaves were treated with $40 \mathrm{~g}$ ai ha ${ }^{-1}$ of imazamox (Pulsar ${ }^{\circledR} 40,4 \%$ w/v, BASF Española S. L., Tarragona, Spain) plus methyl oleate/methyl palmitate adjuvant (Dash $\mathrm{HC}^{\circledR}, 34.8 \% \mathrm{w} / \mathrm{v}, \mathrm{BASF}$ Española S. L.) at $1.25 \mathrm{~L} \mathrm{ha}^{-1}$. Six hours after imazamox treatment, plants were treated again with $750 \mathrm{~g}$ ai ha ${ }^{-1}$ of glufosinate (Finale ${ }^{\circledR}, 15 \%$ w/v, Bayer Hispania S.L., Vila Seca, Spain). Herbicides were applied using a treatment chamber (Devries Manufacturing, Hollandale, MN, USA) equipped with a TeeJet 8002 EVS flat fan nozzle calibrated at $250 \mathrm{kPa}$ to deliver $250 \mathrm{~L} \mathrm{ha}^{-1}$ of application volume at a height of $50 \mathrm{~cm}$.

F1 individuals surviving herbicide application 21 days after treatment (DAT) were selected for self-pollination to obtain non-segregating lines. Two lines (Rados and Helter) with the best traits (height, spikes, grains, tillering, etc.) were multiplied by self-pollinating for five generations. ${ }^{19}$ Twenty plants of each line were sown in 3-L pots (four plants per pot with five replicates) and treated with IMA + GLU $\left(40+750 \mathrm{~g}\right.$ ai ha $\left.{ }^{-1}\right)$ as described above.
The Spanish cultivar Gazul, a high-quality commercial variety susceptible (S) to both herbicides, was included as a control. No segregation was observed after herbicide application, and their herbicide resistance mechanisms were characterized.

\subsection{Dose-response to imazamox and glufosinate}

Susceptibility to imazamox and glufosinate in the Rados and Helter wheat lines was tested separately. The cultivar Gazul (S), as well as the resistant parents, the cultivar Pantera (parental resistant to imazamox) and the line T-590 (parental resistant to glufosinate) were included in the experiments. Wheat plants (one plant per pot in 250-mL pots) with three to four true leaves were treated with the following doses of imazamox: 0, 20, 40, 60, 80, $120,160,200$ and $240 \mathrm{~g}_{\text {ai }} \mathrm{ha}^{-1}$ for the $\mathrm{R}$ plants and $0,2.5,5$, 10, 20, 40 and $60 \mathrm{~g}$ ai ha ${ }^{-1}$ for the $S$ plants; and glufosinate: $0,300,450,600,750,900,1200$ and $1500 \mathrm{~g}$ ai ha ${ }^{-1}$ for the $\mathrm{R}$ plants and $0,8.3,16.7,33.5,75,150$ and $300 \mathrm{~g}$ ai ha-1 for the $\mathrm{S}$ plants. Methyl oleate/methyl palmitate adjuvant was added at $1.25 \mathrm{~L} \mathrm{ha}^{-1}$ in all imazamox treatments. Parents resistant to a certain herbicide were considered susceptible to the opposite herbicide, i.e. the Pantera cultivar and T-590 line were treated with the glufosinate and imazamox doses, respectively, established for $\mathrm{S}$ plants. Herbicide applications were conducted as described above. At 21 DAT, plants were cut at ground level and weighed to determine the fresh weight. The experiments were conducted in a completely randomized design with 12 replicates per dose.

\subsection{Interaction between herbicides}

Three new dose-response assays were carried out on the Rados and Helter lines for each herbicide. The imazamox and glufosinate doses established for $\mathrm{R}$ plants above were applied again. However, when the wheat plants were treated with all doses of a particular herbicide, they received three additional separate doses of the opposite herbicide and vice versa. The additional doses were 20, 40 and $60 \mathrm{~g}$ ai ha ${ }^{-1}$ of imazamox, and 450,600 and $750 \mathrm{~g}$ ai ha ${ }^{-1}$ of glufosinate. These rates correspond to the minimum, intermediate and maximum recommended field rates for each herbicide. Each additional dose of herbicides represented a new dose-response curve. The media and conditions were the same as in the previous dose-response assays. In all cases, glufosinate was applied in sequential application $6 \mathrm{~h}$ after imazamox. At $21 \mathrm{DAT}$, plants were cut at ground level and weighed to determine the fresh weight. The experiments were conducted in a completely randomized design with 12 replications per dose.

\subsection{Foliar herbicide retention}

Wheat plants with three to four true leaves were treated with a solution containing $40+750 \mathrm{~g}$ ai ha ${ }^{-1}$ of IMA + GLU, respectively, plus $1.25 \mathrm{~L} \mathrm{ha}^{-1}$ of methyl oleate/methyl palmitate adjuvant plus $100 \mathrm{mg} \mathrm{L}^{-1} \mathrm{Na}$-fluorescein ${ }^{20}$ under the same conditions as in the dose-response assays. Na-fluorescein was used as a labeling reagent to determine the amount of herbicide solution retained. After treatment, when the herbicide solution on the leaves had dried (20-25 $\mathrm{min}$ ) at room temperature, plants were cut at ground level and shaken vigorously for $30 \mathrm{~s}$ in an Erlenmeyer flask containing $50 \mathrm{~mL}$ of $5 \mathrm{~mm} \mathrm{NaOH}$. The washing solution was recovered in glass flasks and the fluorescein absorbance was measured immediately at $490_{\text {exc }} / 510_{\text {em }} \mathrm{nm}$ (Hitachi F-2500 spectrofluorimeter). The tissues were stored in paper envelopes and dried in an oven at $80^{\circ} \mathrm{C}$ for $72 \mathrm{~h}$. Seven plants of each line or cultivar were used in a completely randomized design. Retention was expressed as $\mu \mathrm{L}$ of herbicide solution (IMA $+\mathrm{GLU}$ ) per $\mathrm{g}$ of dry matter. 


\subsection{Enzyme activity of ALS and GS assays}

Six grams (separated into two 3-g aliquots) of tissue from the youngest expanded leaves per wheat line were taken and immediately powdered using liquid $\mathrm{N}_{2}$.

ALS enzyme activity was determined with $3 \mathrm{~g}$ (first aliquot) per wheat line following the methodology of Hatami et al. ${ }^{21}$ Technical grade imazamox (2-(4-isopropyl-4-methyl-5oxo-2-imidazolin-2-yl)-5-methoxymethylnicotinic acid, $96.5 \%$ purity; Sigma Aldrich, Madrid, Spain) concentrations of 0, 1, 10, $50,100,200,300,400$ and $500 \mu \mathrm{mol} \mathrm{L}^{-1}$ were used. Absorbance of samples was measured with a spectrophotometer (Beckman DU-640, Fullerton, CA, USA) at $520 \mathrm{~nm}$ wavelength. The total content of the extracted protein in the ALS raw extract was measured using kit no. P5656 (Sigma-Aldrich) following the manufacturer's instructions at $595 \mathrm{~nm}$ in the spectrophotometer.

GS activity was determined in vitro using $3 \mathrm{~g}$ (second aliquot) of the three wheat lines. ${ }^{17}$ GS was purified from the raw extract. ${ }^{22}$ GS activity was determined using technical grade glufosinate [(RS)-2-amino-4-(hydroxyl(methyl)phosphonoyl) butanoic acid], (95\% purity, Sigma-Aldrich) at the following concentrations: 0, $6.25,12.5,25,50,100,200$ and $300 \mu \mathrm{mol} \mathrm{L}^{-1}$. The absorbance of samples was measured in the spectrophotometer at $540 \mathrm{~nm}$. The total content of the extracted protein in the GS experiment was measured using the colorimetric method described by Bradford..$^{23}$ The GS specific activity (nmol glutamine $\mathrm{mg}^{-1}$ protein $\mathrm{h}^{-1}$ ) was determined in the absence of herbicide.

The experiments (ALS and GS assays) were repeated three times.

\subsection{ALS sequencing}

Leaf tissue ( $\pm 100 \mathrm{mg}$ per sample) from the Rados and Helter lines and the Gazul cultivar was taken for DNA extraction using the Speed tools DNA Extraction Kit Cat Plant (Biotools B \& M Labs. S.A., Madrid, Spain). The primer pair AHAS21Fwd/AHAS26Rev, ${ }^{24}$ was used to amplify a 617-bp fragment. Polymerase chain reactions (PCR) were set up with Certamp complex enzyme mix (Biotools B $\&$ M Labs) following the manufacturer's instructions. PCR products $(5 \mu \mathrm{L})$ were digested with the restriction enzyme Mspl (Invitrogen, Waltham, MA, USA) to identify three expected ALS alleles (imi3-, imi1 and imi2-ALS genes from genomes $A, B$ or $D$, respectively) of the catalytic subunit present in wheat varieties. ${ }^{24}$ Both PCR and digestion products were resolved on $1 \%$ agarose gels and viewed under UV light. Ten PCR products of each allele and each wheat line/cultivar were sequenced using Sanger technology. ALS sequences were verified and assembled using SeqMan Pro 11 (DNASTAR, Madison, WI, USA) and Geneious 8.1.8 (Biomatters Ltd, Auckland, New Zealand) software, respectively, and compared with the ALS sequences of wheat accessions imi1-AY210407, imi2-AY210408 and imi3-AY273827 from GenBank.

\subsection{Ammonia accumulation}

Leaf discs (50 mg, $5 \mathrm{~mm}$ in diameter) from the youngest fully expanded leaves were placed in $1.5-\mathrm{mL}$ tubes with $200 \mu \mathrm{L}$ of different technical grade glufosinate concentrations $(0,6.25,12.5,25,50$, 100,200 and $300 \mu \mathrm{mol} \mathrm{L}^{-1}$ ) diluted in sucrose/Tween 20 medium. The tubes were sealed with two layers of micropore tape and placed in an incubation chamber at $18^{\circ} \mathrm{C}$ under $150 \mathrm{mmol} \mathrm{m}^{-2} \mathrm{~s}^{-1}$ light intensity for $24 \mathrm{~h}$, and $60 \% \mathrm{RH}$. Ammonia accumulation in $\mathrm{R}$ and $\mathrm{S}$ wheat plants was measured according to leaf disc method described by Dayan et al. ${ }^{25}$ The absorbance of samples was measured with a spectrophotometer at $630 \mathrm{~nm}$ wavelength. The experiments were repeated twice, assessing three samples per glufosinate concentration (each with three replicates) of each wheat line. Ammonia content was determined using ammonium chloride as a standard (Sigma-Aldrich). Ammonia accumulation data were expressed as percentage of control.

\subsection{Absorption and translocation}

Absorption and translocation tests for each herbicide were carried out separately. Both imazamox and glufosinate labeled with ${ }^{14} \mathrm{C}$ were mixed with their respective commercial formulations (Pulsar ${ }^{\circledR} 40$ and Finale ${ }^{\circledR}$, respectively) to prepare a solution with a specific activity of $0.834 \mathrm{kBq} \mu \mathrm{L}^{-1}$. The final concentrations corresponded to $40 \mathrm{~g}$ ai ha ${ }^{-1}$ of imazamox $\left(+1.25 \mathrm{~L} \mathrm{ha}^{-1}\right.$ of methyl oleate/methyl palmitate adjuvant) and $750 \mathrm{~g}$ ai ha ${ }^{-1}$ of glufosinate in a $250 \mathrm{~L} \mathrm{ha}^{-1}$ spray solution. Wheat plants with three to four true leaves were treated with a single $1-\mu \mathrm{L}$ droplet of spray solution $\left(0.834 \mathrm{kBq}\right.$ plant $\left.{ }^{-1}\right)$ of ${ }^{14} \mathrm{C}$-imazamox or ${ }^{14} \mathrm{C}$-glufosinate, on the adaxial surface of the first or second youngest fully expanded leaf. Five plants per wheat line/cultivar were harvested at 3, 6, 12, 24, 48 and $96 \mathrm{~h}$ after treatment (HAT) for imazamox, and at 6, 12, 24, 48 and 72 HAT for glufosinate in a completely random design. The treated leaf was washed three times with $1 \mathrm{~mL}$ of water/acetone $(1: 1 \mathrm{v} / \mathrm{v})$ to recover the non-absorbed ${ }^{14} \mathrm{C}$-herbicide. The washing solution was mixed with $2 \mathrm{~mL}$ of scintillation liquid (Ultima Gold ${ }^{\circledR}$, Packard BioScience BV, Groningen, The Netherlands) and radioactivity quantified by liquid scintillation spectrometry (LSS; Beckman LS 6500, Beckman Coulter Inc.). After washing for each indicated period, whole plants were removed from the pot, divided into treated leaf, rest of shoot plant and roots. The latter plant section was washed carefully with distilled water and excess moisture removed with a paper towel. Sections of each plant were stored individually in flexible combustion cones (Packard BioScience BV), dried in a stove at $60^{\circ} \mathrm{C}$ for 1 week and combusted in a biological oxidizer (Packard Tri Carb 307; Packard Instrument Co., Downers Grove, IL, USA). The $\mathrm{CO}_{2}$ released from the combustion was captured in $18 \mathrm{~mL}$ of a mix of Carbo-Sorb E and Permafluor $(9: 9 \mathrm{v} / \mathrm{v})($ Packard BioScience BV), and the radioactivity quantified by LSS. The percentage of each radiolabeled herbicide absorbed was expressed as [kBq in combusted tissue/(kBq in combusted tissue $+\mathrm{kBq}$ in leaf washes) $] \times 100$.

The translocation of both ${ }^{14} \mathrm{C}$-herbicides was also visualized. Wheat plants were treated and handled for the same periods indicated for each herbicide (three plants per wheat line/cultivar each time) using the same media as in the previous section. However, after removing the non-absorbed ${ }^{14} \mathrm{C}$-herbicides, by washing the treated leaves with water/acetone $(1: 1, v / v)$ and the roots with distilled water, the plants were preserved whole, fixed on filter paper $(25 \times 12.5 \mathrm{~cm})$ and dried at room temperature for 4 days. Samples were then placed on a phosphor plate for $6 \mathrm{~h}$ to visualize the ${ }^{14} \mathrm{C}$-herbicide using a phosphor imager (Cyclone, Perkin-Elmer, Packard Bioscience BV).

\subsection{Statistical analyses}

Data for fresh weight reduction and enzyme activity assays were expressed as a percentage of the control, and subjected to non-linear regression analyses to determine the dose of imazamox and/or glufosinate needed to reduce the fresh weight $\left(G_{50}\right)$ and to inhibit enzyme (ALS or GS) activity $\left(I_{50}\right)$ by $50 \%$ for each soft wheat line. Log-logistic three- or four-parameter models were used: $Y=c+\left\{(d-c) /\left[1+(x / g)^{b}\right]\right\}$ or $\left.Y=d / 1+(x / g)^{b}\right):{ }^{26}$ where $Y$ is the percentage fresh weight or the enzyme activity (ALS or GS) reduction with respect to the control; $c$ is the lower limit; $d$ is the 
(A)

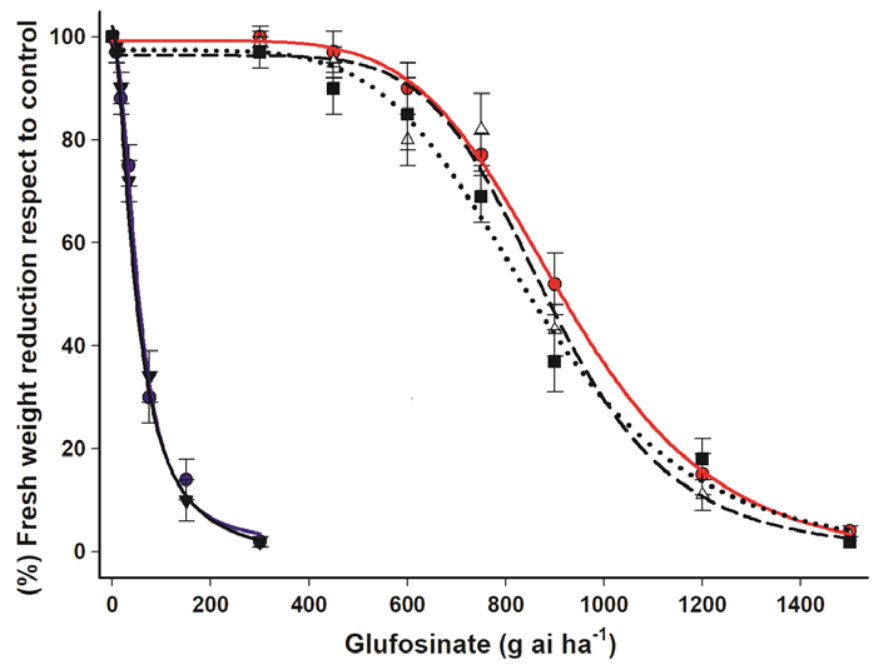

(B)

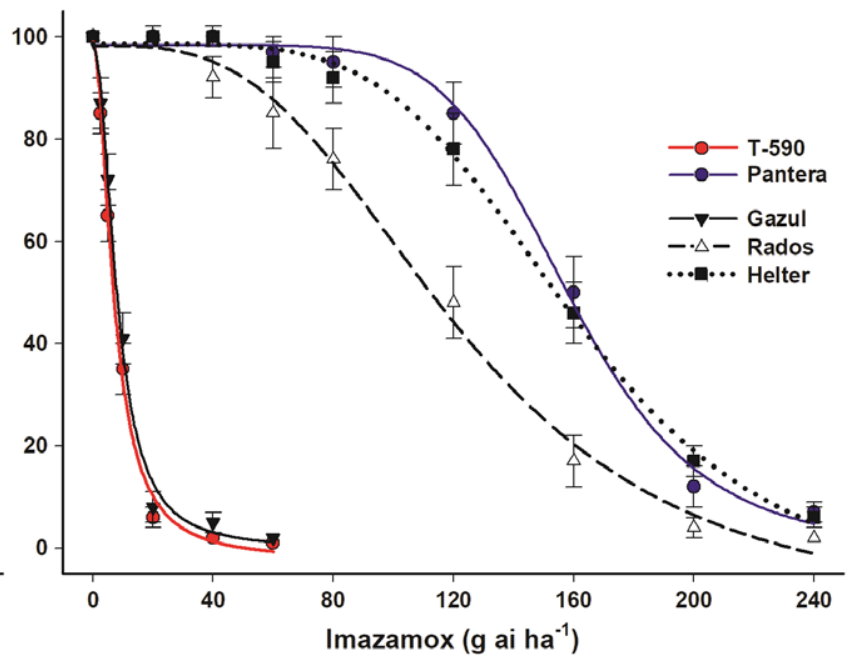

Figure 1. Dose-response curves of glufosinate (A) and imazamox (B) in resistant and susceptible soft wheat plants. The line T-590 (resistant to glufosinate) and the Pantera cultivar (resistant to imazamox) are parental to Rados and Helter, wheat lines with dual resistance to imazamox and glufosinate. The cultivar Gazul was used as a susceptible reference. Vertical bars \pm SE $(n=12)$.

upper limit; $b$ is the slope of the curve at the inflection point; $g$ the herbicide dose at the inflection point; and $x$ is the herbicide dose (independent variable). The three-parameter model assumes that the lower limit is zero. Regression analyses were conducted using the drc package in program R v. 3.2.5, and plotted using SigmaPlot 11.0 (Systat Software, Inc., San Jose, CA, USA). Resistance factors $\left(\mathrm{RF}=\mathrm{R} / \mathrm{S}\right.$ ) were computed as $\mathrm{R}$-to- $\mathrm{S} \mathrm{GR}_{50}$ or $\mathrm{LD}_{50}$ ratios.

Fresh weight reduction data corresponding to the interactions of imazamox $\left(20,40\right.$ and $60 \mathrm{~g}$ ai ha $\left.{ }^{-1}\right) \times$ glufosinate $(450$, 600 and $750 \mathrm{~g}$ ai ha ${ }^{-1}$ ) were subjected to two-way analysis of variance (ANOVA), meanwhile, absorption and translocation of ${ }^{14} \mathrm{C}$-herbicides data were subjected to one-way ANOVA. When required, the Tukey HSD test at $5 \%$ probability was used to separate means using the Statistix software v. 9.0 (Analytical Software, Tallahassee, FL, USA).

\section{RESULTS}

\subsection{Dose-response}

Dual resistance to imazamox and glufosinate was confirmed in the Rados and Helter lines. The $\mathrm{R}$ wheat lines, with similar glufosinate resistance to their resistant parent ( $\mathrm{T}-590$ line), were on average 18-fold more resistant than Gazul, the $S$ cultivar (Fig. 1A). For imazamox, Rados and Helter lines were 15.1- and 19.8-fold more resistant than the $\mathrm{S}$ cultivar, respectively. Helter showed resistance to imazamox similar to that of its imazamox-resistant parent (cultivar Pantera), whereas that of the cultivar Rados was lower by $25 \%$ (Fig. 1B). As expected, parents resistant to a particular herbicide were susceptible to the other herbicide, showing $\mathrm{ED}_{50}$ values similar to the cultivar Gazul in each situation (Fig. 1, Table 1).

\subsection{Interaction between herbicides}

The $\mathrm{GR}_{50}$ values for the Rados and Helter lines, estimated for glufosinate and imazamox, decreased as the doses of the opposite herbicide increased (Table 2); therefore, dose-response curves were shifted to the left in all cases (Fig. 2). The $\mathrm{GR}_{50}$ values for glufosinate in wheat plants treated with $20 \mathrm{~g}$ ai ha ${ }^{-1}$ IMA were similar to those estimated in the glufosinate dose-response curves not treated with imazamox (Table 1). Resistance to glufosinate decreased $\sim 12 \%$ at $60 \mathrm{~g}$ ai ha ${ }^{-1}$ IMA. Resistance to imazamox decreased by between 6-9\% and $20-26 \%$ in wheat plants treated with 450 and $600 \mathrm{~g}$ ai ha ${ }^{-1} \mathrm{GLU}$, respectively. However, this resistance decreased $38 \%$ and $50 \%$ for Rados and Helter, respectively, at $+750 \mathrm{~g}$ ai $\mathrm{ha}^{-1} \mathrm{GLU}$ (Table 2 ). Field rates minimum, intermediate and maximum of the opposite herbicide caused additive effects on the fresh weight reduction of wheat plants, except for the dose-response curves of imazamox with $750 \mathrm{~g}$ ai ha ${ }^{-1} \mathrm{GLU}$, where the effect was synergistic for both cultivars (Fig. 2B,D). The interaction $60+600 \mathrm{~g}$ ai ha-1 IMA $+\mathrm{GLU}$, and any interaction of imazamox $\left(20,40,60 \mathrm{~g}^{\text {ai ha }} \mathrm{ha}^{-1}\right)+750 \mathrm{~g}$ ai ha ${ }^{-1}$ GLU caused the greatest fresh weight reduction rates in wheat plants (Fig. S1).

\subsection{Foliar retention}

Foliar retention (IMA + GLU) did not differ between wheat lines $(P=0.1862$, DF $=2, n=21)$. The herbicide solution retained was $228 \pm 37,214 \pm 32$ and $196 \pm 27 \mu \mathrm{L} \mathrm{g}^{-1}$ dry weight for Helter and Rados lines and the Gazul cultivar, respectively.

\subsection{Enzyme activity tests}

The specific in vitro activities of the ALS enzyme for Rados and Helter lines and the Gazul cultivar were $279 \pm 23,294 \pm 42$ and $284 \pm 28 \mathrm{nmol}$ acetoin $\mathrm{mg}^{-1}$ protein $\mathrm{h}^{-1}$, respectively, with no significant differences $(P=0.2647, \mathrm{DF}=2, n=72)$. Imazamox inhibited the ALS activity in all cultivars as the concentrations increased (Fig. 3A). The amount of imazamox needed to inhibit the ALS enzyme activity of Gazul cultivar by $50 \%\left(I_{50}\right)$ was $11.8 \mu \mathrm{mol} \mathrm{L}^{-1}$. The RF of Rados and Helter lines were 11.7 and 17.7, respectively, compared with the S cultivar (Table 3 ).

The specific in vitro activities of GS enzyme for Rados and Helter lines and the Gazul cultivar were $390 \pm 46,443 \pm 33$ and $421 \pm 62 \mathrm{nmol}$ of glutamine $\mathrm{mg}^{-1}$ protein $\mathrm{h}^{-1}$, respectively, with no significant differences ( $P=0.3486, \mathrm{DF}=2, n=72$ ). Glufosinate inhibited GS activity in all cultivars as the concentrations increased (Fig. 3B). The amount of glufosinate required to inhibit GS activity 
Table 1. Parameters of the sigmoidal equations $\mathrm{s}^{\mathrm{a}}$ used to estimate the dose ( $\mathrm{g}$ ai ha $\mathrm{a}^{\mathrm{a}}$ ) of glufosinate and/or imazamox required to reduce the fresh weight by $50 \%\left(\mathrm{GR}_{50}\right)$ in susceptible and resistant soft wheat plants

\begin{tabular}{|c|c|c|c|c|c|c|}
\hline Cultivar/line & $\mathrm{GR}_{50}(95 \% \mathrm{Cl})^{\mathrm{b}}$ & c & $d$ & b & $P$ & $\mathrm{RF}^{\mathrm{c}}$ \\
\hline \multicolumn{7}{|l|}{ Glufosinate } \\
\hline Gazul & $47.4(7.7)$ & $2.2 \pm 1.9$ & $99.9 \pm 1.5$ & $1.7 \pm 0.3$ & 0.0036 & - \\
\hline Pantera & $53.0(6.2)$ & $1.1 \pm 0.8$ & $98.8 \pm 2.8$ & $2.1 \pm 0.3$ & 0.0014 & 1.1 \\
\hline T-590 & $920.4(72.6)$ & $1.9 \pm 2.2$ & $99.3 \pm 0.5$ & $5.9 \pm 0.3$ & $<0.0001$ & 19.4 \\
\hline Rados & $889.4(46.3)$ & $0.3 \pm 0.1$ & $96.4 \pm 2.6$ & $7.0 \pm 2.2$ & $<0.0001$ & 18.8 \\
\hline Helter & $858.4(54.8)$ & $0.9 \pm 0.4$ & $97.5 \pm 1.8$ & $5.2 \pm 1.0$ & 0.0001 & 18.1 \\
\hline \multicolumn{7}{|l|}{ Imazamox } \\
\hline Gazul & $8.1(0.7)$ & $0.3 \pm 0.2$ & $97.9 \pm 3.8$ & $2.1 \pm 0.3$ & 0.0014 & - \\
\hline Pantera & $168.4(22.4)$ & $0.1 \pm 0.3$ & $98.4 \pm 1.1$ & $7.2 \pm 1.0$ & $<0.0001$ & 20.8 \\
\hline T-590 & $7.1(0.5)$ & $2.3 \pm 1.9$ & $98.9 \pm 3.0$ & $1.9 \pm 0.2$ & 0.0009 & 0.9 \\
\hline Rados & $122.5(19.3)$ & $1.2 \pm 0.8$ & $98.2 \pm 1.6$ & $3.1 \pm 0.5$ & $<0.0001$ & 15.1 \\
\hline Helter & $160.6(24.6)$ & $0.9 \pm 0.7$ & $98.6 \pm 0.9$ & $4.7 \pm 0.6$ & $<0.0001$ & 19.8 \\
\hline
\end{tabular}

Table 2. Parameters of the sigmoidal equations $\mathrm{s}^{\mathrm{a}}$ used to estimate the dose $\left(\mathrm{g}\right.$ ai ha $\mathrm{h}^{-\mathrm{g}}$ ) of glufosinate and/or imazamox, required to reduce the fresh weight by $50 \%\left(\mathrm{GR}_{50}\right)$ on the Rados and Helter lines, in interaction with the minimum, intermediate and maximum field rates of the opposite herbicide

\begin{tabular}{|c|c|c|c|c|c|c|c|}
\hline Cultivar/line & Herbicide interaction & $\mathrm{GR}_{50}(95 \% \mathrm{Cl})^{\mathrm{b}}$ & c & $d$ & $b$ & $P$ & $\mathrm{DR}^{\mathrm{c}}$ \\
\hline & + Imazamox (g ai ha $\left.{ }^{-1}\right)$ & & & Glufosinat & & & \\
\hline \multirow[t]{3}{*}{ Rados $\left(G_{50}=889.4\right)$} & 20 & $894.2(52.1)$ & $0.1 \pm 0.0$ & $96.9 \pm 1.7$ & $7.3 \pm 1.0$ & $<0.0001$ & 1.00 \\
\hline & 40 & $864.7(43.8)$ & $2.8 \pm 1.3$ & $97.7 \pm 1.5$ & $5.9 \pm 0.6$ & $<0.0001$ & 0.97 \\
\hline & 60 & $783.7(69.2)$ & $3.7 \pm 1.5$ & $96.5 \pm 4.4$ & $4.8 \pm 1.3$ & $<0.0001$ & 0.88 \\
\hline \multirow[t]{4}{*}{ Helter $\left(G_{50}=858.4\right)$} & 20 & $842.0(30.8)$ & $6.1 \pm 4.1$ & $96.0 \pm 2.7$ & $9.4 \pm 2.1$ & $<0.0001$ & 0.98 \\
\hline & 40 & $806.7(40.6)$ & $3.2 \pm 2.8$ & $97.7 \pm 1.7$ & $6.4 \pm 0.7$ & $<0.0001$ & 0.93 \\
\hline & 60 & $765.3(47.3)$ & $1.5 \pm 1.3$ & $95.0 \pm 3.0$ & $6.6 \pm 1.3$ & $<0.0001$ & 0.89 \\
\hline & + Glufosinate ( $\mathrm{g}$ ai ha ${ }^{-1}$ ) & & & Imazamox & & & \\
\hline \multirow[t]{3}{*}{ Rados $\left(G_{50}=122.5\right)$} & 450 & $112.0(11.7)$ & - & $96.7 \pm 2.0$ & $3.6 \pm 0.5$ & $<0.0001$ & 0.91 \\
\hline & 600 & $98.7(8.2)$ & - & $94.4 \pm 3.1$ & $2.8 \pm 0.5$ & $<0.0001$ & 0.80 \\
\hline & 750 & $76.4(17.8)$ & - & $95.3 \pm 5.9$ & $1.7 \pm 0.5$ & 0.0060 & 0.62 \\
\hline \multirow[t]{3}{*}{ Helter $\left(\mathrm{GR}_{50}=160.6\right)$} & 450 & $151.0(14.2)$ & - & $97.7 \pm 1.6$ & $2.4 \pm 0.3$ & 0.0001 & 0.94 \\
\hline & 600 & $119.2(16.4)$ & - & $94.5 \pm 3.7$ & $2.6 \pm 0.6$ & 0.0008 & 0.74 \\
\hline & 750 & $81.9(25.7)$ & - & $97.9 \pm 5.5$ & $1.3 \pm 0.4$ & 0.0244 & 0.50 \\
\hline \multicolumn{8}{|c|}{$\begin{array}{l}\left.\text { a } Y=c+\left\{(d-c) /\left[1+(x / g)^{b}\right]\right\} \text { (four parameters) } \dagger \text { or } Y=d / 1+(x / g)^{b} \text { (three parameters) }\right) \text { : where } Y \text { is the percentage of fresh weight reduction with } \\
\left.\text { respect to the control, } c \text { is lower limit, } d \text { the upper limit, } b \text { the slope of the curve, } g \text { the herbicide concentration at the inflection point (i.e. } G R_{50}\right) \text {, and } \\
x \text { is the herbicide concentration. The three-parameter model assumes that the lower limit is zero. } \\
{ }^{b} \mathrm{Cl} \text { values are the } 95 \% \text { limits of confidence intervals }(n=12) \text {. } \\
{ }^{c} \text { Decrease in resistance (DR }=\mathrm{GR}_{50} \text { of a wheat line treated with an additional dose of the opposite herbicide/GR } \\
\text { respective wheat line). }\end{array}$} \\
\hline
\end{tabular}

by $50 \%\left(I_{50}\right)$ ranged from 15.7 to $21.1 \mu \mathrm{mol} \mathrm{L}^{-1}$. According to the $95 \%$ limits of confidence intervals $(\mathrm{Cl})$, there were no differences between $\mathrm{R}$ and $\mathrm{S}$ wheat lines (Table 3 ).

\subsection{ALS sequencing}

The amino acid sequences of Gazul cultivar (S) had the same consensus as the ALS sequences of wheat accessions from GenBank (imi1-AY210407, imi2-AY210408 and imi3-AY273827). The line Helter contained the Ser653-Asn mutation in the imi1- and imi2-ALS genes, whereas the line Rados contained the same mutation only in the imi2-ALS gene. The codon changes were AAC to AGC. No mutation was found in the imi3 gene (Fig. 4).

\subsection{Ammonia accumulation}

The $S$ and $R$ lines accumulated ammonia at different levels. From 0 to $100 \mu \mathrm{mol} \mathrm{L}^{-1}$ of glufosinate, ammonia accumulation was similar. However, Gazul cultivar showed the highest ammonium accumulation ( $365 \pm 88 \mu \mathrm{g}$ of ammonia per $\mathrm{g}$ fresh weight) at $300 \mu \mathrm{mol} \mathrm{L}^{-1}$ of glufosinate. At this glufosinate concentration, Helter and Rados lines accumulated at least $60 \%$ less ammonia than Gazul cultivar (Fig. 5).

\subsection{Absorption and translocation}

More than $50 \%$ of ${ }^{14} \mathrm{C}$-imazamox was absorbed within three HAT for all cultivars. Initially ( 3 to 12 HAT), the R lines absorbed greater amounts of herbicide than the S cultivar Gazul, but from 24 HAT 


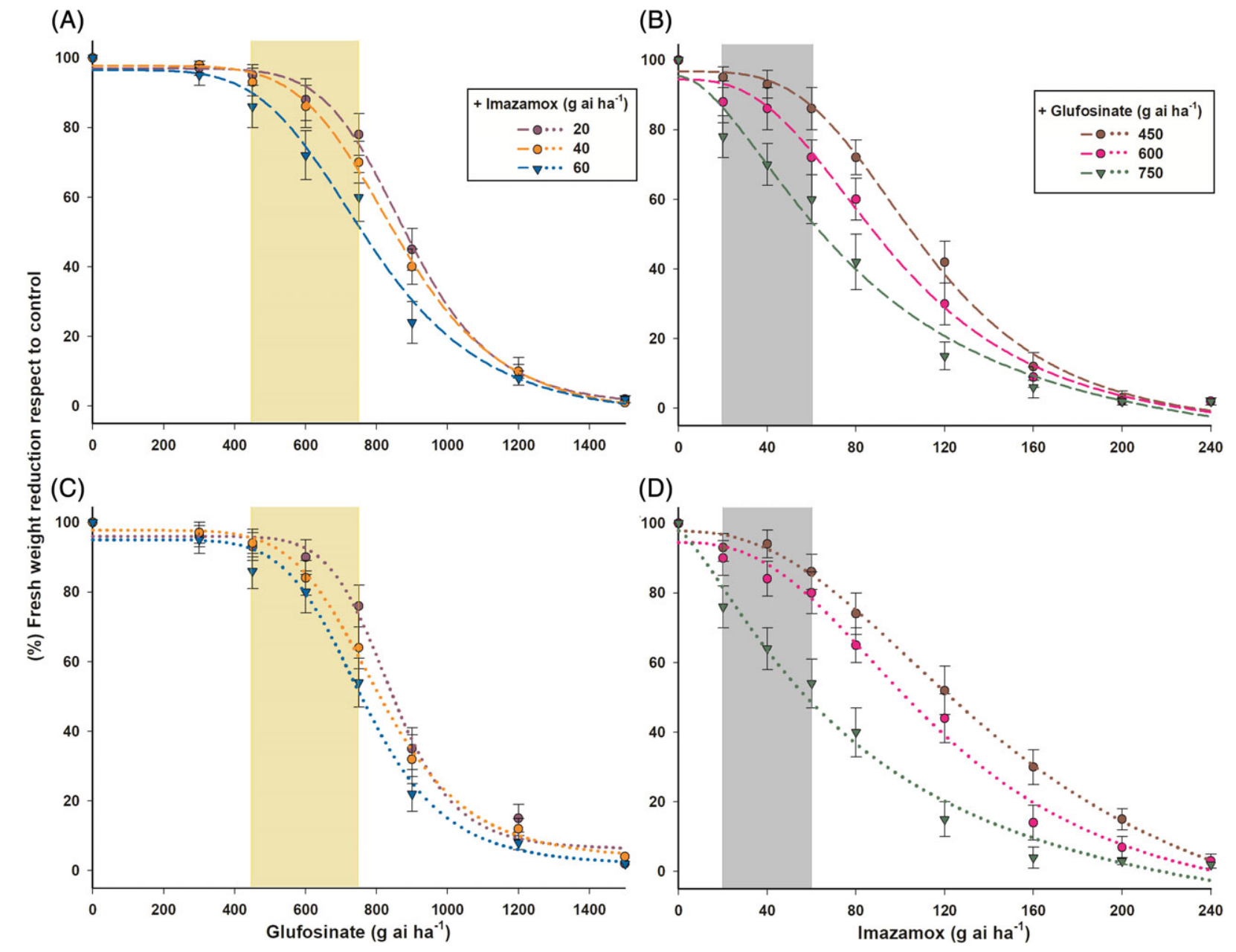

(B)

Figure 2. Dose-response curves of glufosinate $(A, C)$ and imazamox $(B, D)$ in interaction with the opposite herbicide on the wheat lines Rados (dashed lines) and Helter (dotted lines) with dual resistance to both herbicides. In all cases, glufosinate was applied $6 \mathrm{~h}$ after imazamox application. Boxes within the plots highlight the interaction of the minimum, intermediate and maximum recommended field rates between herbicides. Vertical bars $\pm \mathrm{SE}(n=12)$.

no differences were observed in the absorption between $\mathrm{R}$ and $\mathrm{S}$ wheat lines, with all showing $>90 \%{ }^{14} \mathrm{C}$-imazamox absorption (Fig. 6A). The $R$ and $S$ wheat plants showed high rates of ${ }^{14} \mathrm{C}$-imazamox translocation from the treated leaf to the rest of the plant and roots. In the first 3 to 12 HAT, the ${ }^{14} \mathrm{C}$-imazamox was mainly retained in the treated leaf, but from $24 \mathrm{HAT}$, extensive translocation to the rest of the plant and roots was observed. At $96 \mathrm{HAT}$, the ${ }^{14} \mathrm{C}$-imazamox amount, quantified in each evaluated section of the plant, was similar between the wheat lines, ranging from $30 \%$ to $40 \%$ (Fig. 6B, Fig. S1).

Foliar ${ }^{14} \mathrm{C}$-glufosinate absorption rates were $<40 \%$ of the total applied at the longest evaluated period (72 HAT). Differences in translocation rates were observed at 6, 24 and 48 HAT. The two $\mathrm{R}$ lines absorbed slightly more herbicide than the $\mathrm{S}$ cultivar (Fig. 6C). The $\mathrm{R}$ and $\mathrm{S}$ plants showed low translocation rates of ${ }^{14} \mathrm{C}$-glufosinate with no difference among lines, with the majority of herbicide $(>75 \%)$ retained on the treated leaf. The amounts of ${ }^{14} \mathrm{C}$-glufosinate translocated to the rest of the plant and roots were $<15 \%$ and $10 \%$, respectively (Fig. 6D, Fig. S2).

\section{DISCUSSION}

Effective weed management without herbicide use is not currently viable in conventional intensive wheat production systems. ${ }^{3}$ In this work, two new $\mathrm{R}$ wheat lines, with stacked traits conferring multiple resistance to imazamox and glufosinate, were characterized.

Rados and Helter lines presented acceptable levels of dual resistance to both herbicides. As per herbicide label, field rates of imazamox ${ }^{27}$ and glufosinate ${ }^{28}$ range from 20 to 60 and from 450 to $750 \mathrm{~g}$ ai ha ${ }^{-1}$, respectively, depending on the cropping system, weed species and infestation level. The $\mathrm{GR}_{50}$ values of imazamox and glufosinate estimated for the $\mathrm{R}$ lines were above these recommended doses. Differences between the wheat $\mathrm{R}$ lines were due to their differential susceptibility to imazamox as discussed later.

The $\mathrm{GR}_{50}$ values for imazamox estimated for Rados and Helter were 122.5 and $160.6 \mathrm{~g}$ ai ha ${ }^{-1}$, respectively. Imazamox doses $\left(20,40\right.$ or $\left.60 \mathrm{~g}_{\text {ai ha }}{ }^{-1}\right)$ applied in the glufosinate dose-response curves were at least twofold lower than these values, and resistance to glufosinate of $\mathrm{R}$ wheat lines was reduced only slightly. By contrast, the $\mathrm{ED}_{50}$ values of glufosinate for both lines were close to the maximum dose of this herbicide applied in the imazamox dose-response curves; therefore, resistance to imazamox in Rados and Helter lines was drastically reduced when plants were treated with $+750 \mathrm{~g}$ ai ha ${ }^{-1}$ glufosinate. Additive or synergistic effects of herbicides are desirable for weed control, but not for crop safety. ${ }^{29}$ Although the sequential application of imazamox + glufosinate led to additive effects, the interactions between minimum and intermediate doses did not compromise the growth of Rados and 

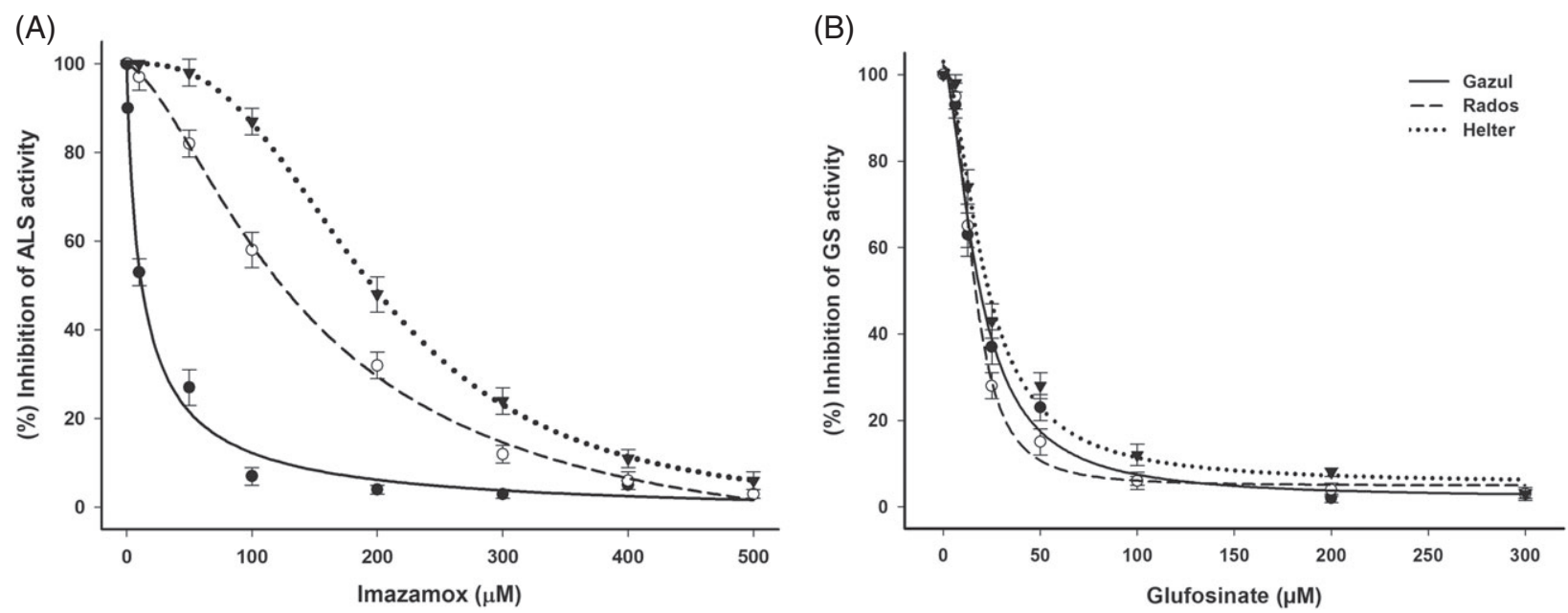

Figure 3. Log-logistic curves of enzymatic activity of the (A) acetolactate synthase (ALS) and (B) glutamine synthase (GS) in soft wheat plants of the lines Rados and Helter, with dual resistance to imazamox and glufosinate, and the susceptible cultivar Gazul. Vertical bars \pm SE $(n=3)$.

Table 3. Parameters of the sigmoidal equations $s^{\mathrm{a}}$ used to estimate the concentrations $(\mu \mathrm{M})$ of glufosinate and/or imazamox needed to inhibit the enzymatic activity of the ALS and GS by $50 \%\left(I_{50}\right)$, respectively, in susceptible and resistant soft wheat plants

\begin{tabular}{|c|c|c|c|c|c|c|}
\hline Cultivar/line & $I_{50}(95 \% \mathrm{Cl})^{\mathrm{b}}$ & c & $d$ & b & $P$ & RF \\
\hline \multicolumn{7}{|l|}{ Glufosinate $^{\dagger}$} \\
\hline Gazul & $18.0(4.7)$ & $1.9 \pm 1.1$ & $102.2 \pm 4.5$ & $1.7 \pm 0.3$ & 0.0010 & - \\
\hline Rados & $15.7(5.1)$ & $4.8 \pm 1.8$ & $101.8 \pm 2.8$ & $2.4 \pm 0.3$ & $<0.0001$ & 0.9 \\
\hline Helter & $21.1(7.2)$ & $1.7 \pm 0.7$ & $103.0 \pm 3.3$ & $1.8 \pm 0.3$ & 0.0010 & 1.2 \\
\hline \multicolumn{7}{|l|}{ Imazamox } \\
\hline Gazul & $11.8(3.4)$ & - & $100.0 \pm 3.6$ & $0.9 \pm 0.1$ & 0.0039 & - \\
\hline Rados & $137.6(15.1)$ & - & $99.9 \pm 1.1$ & $1.6 \pm 0.1$ & $<0.0001$ & 11.7 \\
\hline Helter & $208.7(19.8)$ & - & $99.8 \pm 0.3$ & $2.8 \pm 0.1$ & $<0.0001$ & 17.7 \\
\hline
\end{tabular}

${ }^{a} Y=c+\left\{(d-c) /\left[1+(x / g)^{b}\right]\right\}$ (four parameters) $\dagger$ or $Y=d / 1+(x / g)^{b}$ (three parameters) $\ddagger$ : where $Y$ is the percentage of enzyme activity with respect to the control, $c$ is the lower limit, $d$ the upper limit, $b$ the slope of the curve, $g$ the herbicide concentration at the inflection point (i.e. $I_{50}$ ), and $x$ is the herbicide concentration. The three-parameter model assumes that the lower limit is zero.

${ }^{\mathrm{b}} \mathrm{Cl}$ values are the $95 \%$ limits of confidence intervals $(n=3)$.

c Resistance factor $\left(\mathrm{RF}=I_{50} \mathrm{R} / I_{50} \mathrm{~S}\right)$.

\begin{tabular}{cc} 
Amino acid position & \multicolumn{1}{c}{650} \\
Imi1-AY210407 & PHQEHVLPMIPSGGAFKDMIMEGD \\
Imi2-AY210408 & PHQEHVLPMIPSGGAFKDMIMEGD \\
Imi3-AY273827 & PHQEHVLPMIPSGGAFKDMIMEGD \\
Imi1-Gazul & PHQEHVLPMIPSGGAFKDMIMEGD \\
Imi2-Gazul & PHQEHVLPMIPSGGAFKDMIMEGD \\
Imi3-Gazul & PHQEHVLPMIPSGGAFKDMIMEGD \\
Imi1-Rados & PHQEHVLPMIPSGGAFKDMIMEGD \\
Imi2-Rados & PHQEHVLPMIPNGGAFKDMIMEGD \\
Imi3-Rados & PHQEHVLPMIPSGGAFKDMIMEGD \\
Imi1-Helter & PHQEHVLPMIPNGGAFKDMIMEGD \\
Imi2-Helter & PHQEHVLPMIPNGGAFKDMIMEGD \\
Imi3-Helter & PHQEHVLPMIPSGGAFKDMIMEGD
\end{tabular}

Figure 4. Partial alignment of deduced amino acid sequence of the imi-ALS genes sequences in soft wheat plants of the lines Rados and Helter, with dual resistance to imazamox and glufosinate, and the susceptible cultivar Gazul. Highlighted letters indicate the Ser653 position corresponding to the point mutation associated with conferring of resistance to imazamox. Red letters indicate a codon change from AAC (serine $=S$ ) to AGC (asparagine $=\mathrm{N}$ ). Amino acid number based on the $A$. thaliana ALS sequence (GenBank accession no.: AY042819).
Helter plants. Thus, combinations of $20+450,20+600,40+450$, $40+600$ and $60+450 \mathrm{~g}$ ai ha ${ }^{-1}$ IMA + GLU may be applied during the same cropping season. However, the maximum dose of glufosinate $\left(750 \mathrm{~g}\right.$ ai ha $\left.{ }^{-1}\right)$ had synergistic effects in combination with imazamox; therefore, application of this dose it is not recommended. In addition, Helter and Rados lines were more resistant when exposed to these herbicides separately, which could facilitate the rotation of herbicides between cropping seasons. This practice and the correct adoption of HR crops may contribute to mitigating the increasing problems with HR weeds. ${ }^{\text {? }}$

$\mathrm{R}$ and $\mathrm{S}$ wheat plants presented similar foliar retention of herbicide solution, suggesting that this parameter did not play an important role in the dual resistance to imazamox and glufosinate in Rados and Helter lines. In addition, differences in the foliar retention of imazamox solution were observed among wheat cultivars/lines, $\mathrm{S}$ or $\mathrm{R}$, but this did not influence the resistance levels. ${ }^{30}$

The greater $I_{50}$ value of ALS enzyme in the $R$ wheat lines, Rados and Helter, indicates alterations in the target site. This suggests that the ALS-imi1 and ALS-imi2 resistant genes, with mutation Ser653-Asn from the imazamox-resistant cultivar Pantera (parent), ${ }^{15}$ were transferred to the $\mathrm{R}$ wheat lines. Differences in imazamox susceptibility between the $\mathrm{R}$ lines, as demonstrated in 


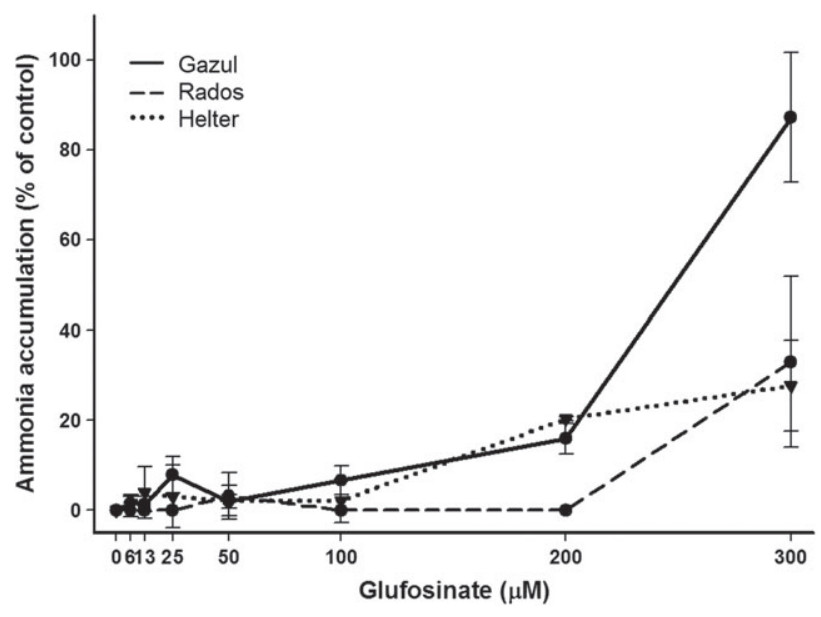

Figure 5. Accumulation of ammonia (\%) at different concentrations $(\mu \mathrm{M})$ of glufosinate in soft wheat plants of the lines Rados and Helter, with dual resistance to imazamox and glufosinate, and the susceptible cultivar Gazul. Vertical bars \pm SE $(n=3)$.
ALS gene sequencing, were due to the Helter line acquiring both resistant genes (ALS-imi1 and ALS-imi2) from the Pantera cultivar, whereas the Rados line acquired only one (ALS-imi2). Generally, Clearfield ${ }^{\circledR}$ crops carry only the mutation in the ALS-imi2 gene, which is enough to confer resistance to imazamox ${ }^{16,31}$ at recommended field doses $\left(40 \mathrm{~g}_{\text {ia }} \mathrm{ha}^{-1}\right.$ ). Similar differences in imazamox susceptibility were observed in Clearfield ${ }^{\circledR}$ wheat cultivars ${ }^{14-16}$ and other Clearfield ${ }^{\circledR}$ crops, $^{31}$ carrying the single and/or double mutation in the imi1-ALS and imi2-ALS genes, respectively. However, the similar susceptibility of the GS to glufosinate in wheat plants $R$ and $S$, suggested that there are no mutations in the GS gene involved in the resistance of Helter and Rados lines to this herbicide.

The similar specific ALS and GS activities of the wheat lines (both $\mathrm{R}$ and $\mathrm{S}$ ) in the absence of herbicides (imazamox and glufosinate, respectively), suggested that overexpression of both ALS and GS enzymes was not involved in the multiple resistance to imazamox and glufosinate of Rados and Helter lines. The large accumulation of ammonia in Gazul, the $S$ cultivar, showed a rapid inhibition of GS activity by glufosinate in this cultivar. Ammonia accumulation
(A)

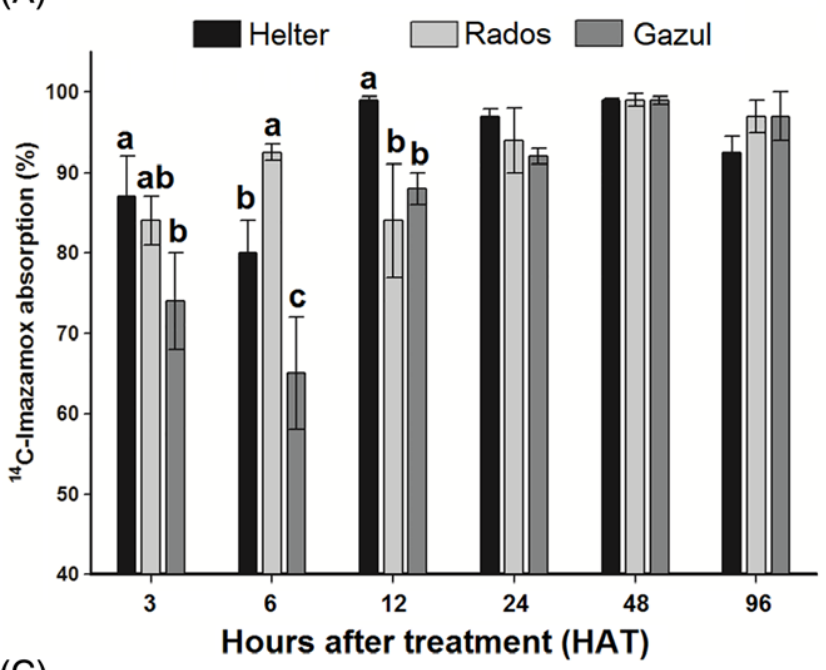

(C)

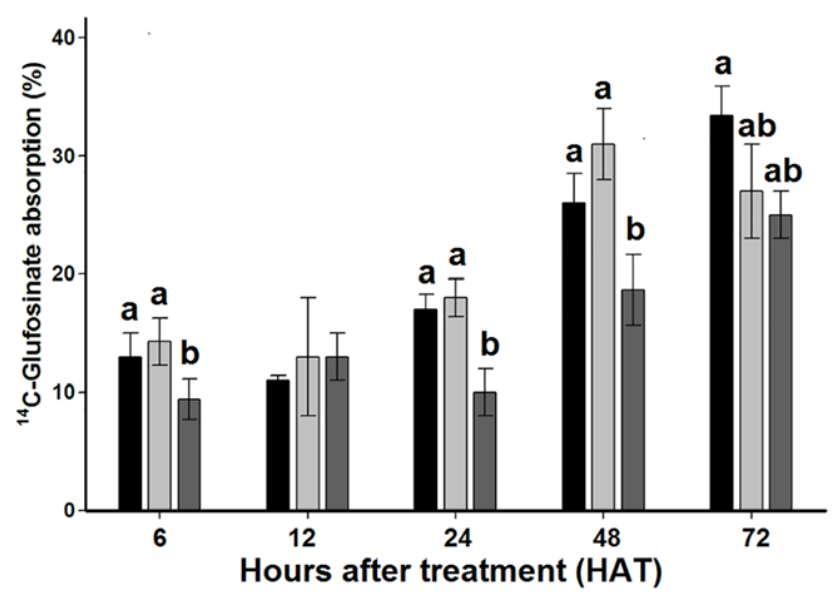

(B)

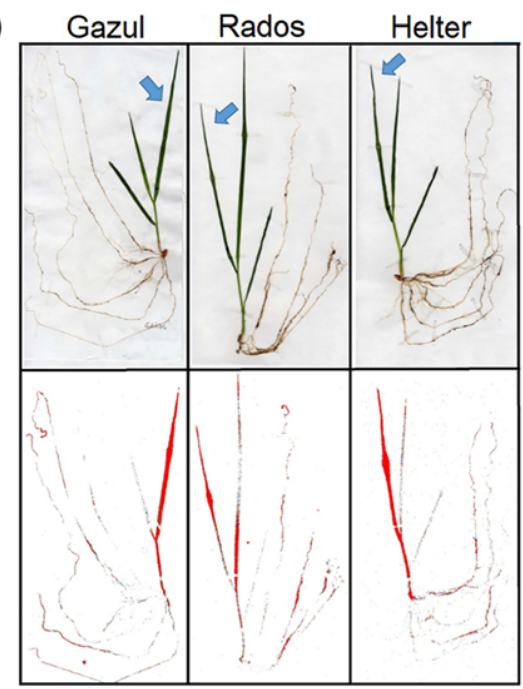

(D)

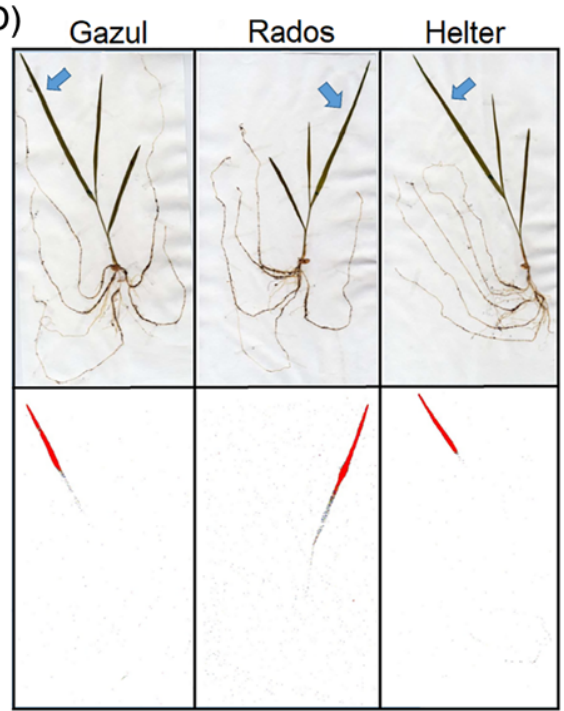

Figure 6. Absorption of ${ }^{14} \mathrm{C}$-imazamox (A) and ${ }^{14} \mathrm{C}$-glufosinate (C) from 3 to $96 \mathrm{~h}$ after treatment (HAT) and from 6 to $72 \mathrm{HAT}$, respectively, in soft wheat plants of the lines Rados and Helter, with dual resistance to imazamox and glufosinate, and the susceptible cultivar Gazul. Vertical bars represent \pm SE $(n=5)$. Digital and autoradiograph images of ${ }^{14} \mathrm{C}$-imazamox (B) and ${ }^{14} \mathrm{C}$-glufosinate (D) translocation at $96 \mathrm{HAT}$. The red color indicates a higher concentration of ${ }^{14} \mathrm{C}$-herbicide. Arrows indicate the treated leaf. 
is an indicator of the susceptibility of the GS enzyme to glufosinate toxicity. ${ }^{32}$ The lower accumulation of ammonia in R-wheat lines indicates that GS activity was not impaired by glufosinate. ${ }^{13}$ This was presumably due to rapid acetylation of the glufosinate to $\mathrm{N}$-acetyl-glufosinate (non-toxic compound) mediated by the PAT enzyme. This enzyme caused low ammonia accumulation in glufosinate-resistant cotton ${ }^{13}$ and rice ${ }^{33}$ that carried the bar gene. Once this gene is responsible for encoding the PAT enzyme, and considering the accumulation of ammonia as an indicator of resistance in glufosinate-resistant crops, we concluded that the Helter and Rados lines acquired and conserved the bar gene from their glufosinate-resistant parent, the T-590 line, ${ }^{17,18}$ after crossing with the cultivar Pantera.

The $\mathrm{R}$ and $\mathrm{S}$ wheat lines showed high absorption and translocation patterns of ${ }^{14} \mathrm{C}$-imazamox. During the first HAT (3 to 12 HAT), there were differences in absorption between wheat lines. This parameter was higher in $\mathrm{R}$ than in $\mathrm{S}$ wheat plants during this period, but translocation of ${ }^{14} \mathrm{C}$-imazamox was similar between them during the evaluation period ( 3 to $96 \mathrm{HAT}$ ). Reduced absorption and translocation may have an important role in the resistance to other herbicides such as glyphosate, ${ }^{34,35}$ but in the resistance to ALS-inhibiting herbicides this role is secondary. ${ }^{11}$ This suggests that these non-target site mechanisms were not involved in the resistance to imazamox of these $R$ wheat lines.

Unlike imazamox, the absorption and translocation patterns of ${ }^{14} \mathrm{C}$-glufosinate were lower, because this herbicide has low or no mobility due to its rapid phytotoxicity in the source leaf tissue. ${ }^{28,36}$ This explain the low amounts of glufosinate absorbed and translocated in the $\mathrm{R}$ and $\mathrm{S}$ wheat plants. The limited translocation of ${ }^{14} \mathrm{C}$-glufosinate may be a consequence of the combined effects of ammonia accumulation, reduced carbon accumulation and glutamine depletion. ${ }^{17,32,37}$ These processes occurred rapidly in $\mathrm{S}$ plants, killing their leaf tissues, and explaining why these plants show lower absorption and translocation rates for ${ }^{14} \mathrm{C}$-glufosinate in comparison with $\mathrm{R}$ plants. Therefore, the absorption and translocation of these herbicides were not involved in the resistance to glufosinate of the $\mathrm{R}$ wheat lines.

\section{CONCLUSIONS}

The $\mathrm{R}$ wheat lines, Rados and Helter, showed high levels of resistance to imazamox and glufosinate. Stacked traits conferring this dual herbicide resistance were obtained from their respective glufosinate- and imazamox-resistant parents.

Sequential application of low or intermediate field rates of imazamox + glufosinate during the same cropping season does not compromise plant growth in $\mathrm{R}$ wheat. However, the resistance of Rados and Helter lines is higher when exposed to these herbicides independently, facilitating rotation of herbicides. Therefore, these $\mathrm{R}$ lines are an effective weed management tool for wheat production, and may also contribute to mitigating the increasing problem of HR weeds.

\section{ACKNOWLEDGEMENTS}

This study was supported by Projects AGL 2016-2078944-R (Spain) and CONACYT-242088 (Mexico). The authors would thank BASF International (Frankfurt, Germany) and Dr. C. Gauvrit (INRA-Dijon, France) for delivery ${ }^{14} \mathrm{C}$-imazamox and ${ }^{14} \mathrm{C}$-glufosinate, respectively, as well as Rafael Roldan for his assistance with the experiments, and the Dr. Antonio P. Martín from the Plant Breeding research group of the Institute for Sustainable
Agriculture, IAS-CSIC, Cordoba, Spain, by the obtainment of wheat lines Rados and Helter. Dr. Phillip Villani (The University of Melbourne) revised and corrected the English language used in this manuscript.

\section{SUPPORTING INFORMATION}

Supporting information may be found in the online version of this article.

\section{REFERENCES}

1 Food and Agriculture Organization of the United Nations (FAO) (2017). FAO cereal supply and demand brief. [Online]. FAO. Available: http:// www.fao.org/worldfoodsituation/csdb/en/ [12 November 2017].

2 Rojano-Delgado AM, Priego-Capote F, Luque de Castro MD and De Prado $R$, Mechanism of imazamox resistance of the Clearfield ${ }^{\circledR}$ wheat cultivar for better weed control. Agron Sustain Dev 35: 639-648 (2015)

3 Jabran K, Mahmood K, Melander B, Bajwa AA and Kudsk P, Weed dynamics and management in wheat. Adv Agron 145:97-166 (2017).

4 Bonny S, Genetically modified herbicide-resistant crops, weeds, and herbicides: overview and impact. Environ Manage 57:31-48 (2016).

5 Green JM, Current state of herbicides in herbicide-resistant crops. Pest Manag Sci 70:1351 - 1357 (2014).

6 Green JM, The rise and future of glyphosate and glyphosate-resistant crops. Pest Manag Sci 74:1035-1039 (2018).

7 Lamichhane JR, Devos Y, Beckie HJ, Owen MKD, Tillie P, Messean A et al. Integrated weed management systems with herbicide-resistant crops in the European Union: lessons learnt from home and abroad. Crit Rev Biotechnol 37:459-475 (2017).

8 Gressel J, Gassmann AJ and Owen MDK, How well will stacked transgenic pest/herbicide resistances delay pests from evolving resistance? Pest Manag Sci 73:22-34 (2017).

9 Shaner DL and Beckie HJ, The future for weed control and technology. Pest Manag Sci 70:1329-1339 (2014).

10 Beckie HJ and Harker KN, Our top 10 herbicide-resistant weed management practices. Pest Manag Sci 73:1045-1052 (2017).

11 Yu Q and Powles SB, Resistance to AHAS inhibitor herbicides: current understanding. Pest Manag Sci 70:1340-1350 (2014).

12 Everman WJ, Burke IC, Allen JR, Collins J and Wilcut JW, Absorption, translocation, and metabolism of ${ }^{14} \mathrm{C}$-glufosinate in glufosinateresistant corn, goosegrass (Eleusine indica), large crabgrass (Digitaria sanguinalis), and sicklepod (Senna obtusifolia). Weed Sci 57:1-5 (2009).

13 Carbonari CA, Latorre DO, Gomes GL, Velini ED, Owens DK, Pan Z et al., Resistance to glufosinate is proportional to phosphinothricin acetyltransferase expression and activity in Liberty Link ${ }^{\circledR}$ and WideStrike ${ }^{\circledR}$ cotton. Planta 243:925-933 (2016).

14 Domínguez-Mendez R, Alcántara-de la Cruz R, Rojano-Delgado AM, Fernández-Moreno PT, Aponte R and De Prado R, Multiple mechanisms are involved in new imazamox-resistant varieties of durum and soft wheat. Sci Rep 7:14839 (2017).

15 Jimenez F, Rojano-Delgado AM, Fernández PT, Rodríguez-Suárez C, Atienza SG and De Prado R, Physiological, biochemical and molecular characterization of an induced mutation conferring imidazolinone resistance in wheat. Physiol Plant 158:2-10 (2016).

16 Pozniak CJ and Hucl PJ, Genetic analysis of imidazolinone resistance in mutation-derived lines of common wheat. Crop Sci 44:23-30 (2004).

17 Rojano-Delgado AM, Priego-Capote F, Barro F, Luque de Castro MD and De Prado R, Liquid chromatography-diode array detection to study the metabolism of glufosinate in Triticum aestivum T-590 and influence of the genetic modification on its resistance. Phytochemistry 96:117-122 (2013).

18 León E, Marín S, Giménez MJ, Piston F, Rodríguez-Quijano M, Shewry PR et al., Mixing properties and dough functionality of transgenic lines of a commercial wheat cultivar expressing the $1 \mathrm{Ax} 1,1 \mathrm{D} \times 5$ and 1Dy10 HMW glutenin subunit genes. J Cereal Sci 49:148-156 (2009).

19 Barro F, Barcelo P, Lazzeri PA, Shewry R, Martín A and Ballesteros J, Field evaluation and agronomic performance of transgenic wheat. Theor Appl Genet 105:980-984 (2002). 
20 Gauvrit C, Glyphosate response to calcium, ethoxylated amine surfactant, and ammonium sulfate. Weed Technol 17:799-804 (2003).

21 Hatami ZM, Gherekhloo J, Rojano-Delgado AM, Osuna MD, Alcántara R, Fernández $\mathrm{P}$ et al., Multiple mechanisms increase levels of resistance in Rapistrum rugosum to ALS herbicides. Front Plant Sci 7:169 (2016).

22 Forlani G, Purification and properties of a cytosolic glutamine synthetase expressed in Nicotiana plumbaginifolia cultured cells. Plant Physiol Biochem 38:201-207 (2000).

23 Bradford MM, A rapid and sensitive method for the quantitation of microgram quantities of protein utilizing the principle of protein dye binding. Anal Biochem 72:248-254 (1976).

24 Pozniak CJ, Birk IT, O'Donoughue LS, Ménard C, Hucl PJ and Singh BK, Physiological and molecular characterization of mutation-derived imidazolinone resistance in spring wheat. Crop Sci 44:1434-1443 (2004).

25 Dayan FE, Owens DK, Corniani N, Silva FML, Watson SB, Howell J et al., Biochemical markers and enzyme assays for herbicide mode of action and resistance studies. Weed Sci 63:23-63 (2015).

26 Ritz C, Baty F, Streibig JC and Gerhard D, Dose-response analysis using R. PLoS One 10:e0146021 (2015).

27 BASF Crop Protection Spain (2018) Trade label of Pulsar ${ }^{\circledR}$ 40 - imazamox $4 \%$ w/v. [Online]. BASF Crop Protection Spain. Available: https://www.agro.basf.es/agroportal/es/es/crop_protection/ crop_protectionproduct_catalogue/product_details_1765.html [12 July 2018].

28 Bayer CropScience Spain (2018) Trade label of Finale ${ }^{\circledR}$ - glufosinate $15 \%$ w/v. [Online]. Bayer CropScience Spain. Available: https://www. cropscience.bayer.es/Productos/Herbicidas/Finale.aspx $\left[\begin{array}{ll}12 & \text { July }\end{array}\right.$ 2018].
29 Cedergreen N, Quantifying synergy: a systematic review of mixture toxicity studies within environmental toxicology. PLoS One 9:e96580 (2014).

30 Jiménez $\mathrm{F}$, Fernández $\mathrm{P}$, Rojano-Delgado AM, Alcantara $\mathrm{R}$ and De Prado R, Resistance to imazamox in Clearfield soft wheat (Triticum aestivum L.). Crop Prot 78:15-19 (2015).

31 Lee H, Rustgi S, Kumar N, Burke I, Yenish JP, Gill KS et al., Single nucleotide mutation in the barley acetohydroxy acid synthase (AHAS) gene confers resistance to imidazolinone herbicides. Proc Natl Acad Sci U S A 108:8909-8913 (2011).

32 Beriault JN, Horsman GP and Devine MD, Phloem transport of $\mathrm{D}, \mathrm{L}$-glufosinate and acetyl-L-glufosinate in glufosinate-resistant and -susceptible Brassica napus. Plant Physiol 121:619-628 (1999).

33 Tsai CJ, Wang CS and Wang CY, Physiological characteristics of glufosinate resistance in rice. Weed Sci 54:634-640 (2006).

34 Shaner DL, Role of translocation as a mechanism of resistance to glyphosate. Weed Sci 57:118-123 (2009).

35 Dominguez-Valenzuela JA, Gherekhloo J, Fernández-Moreno PT, Cruz-Hipolito HE, Alcántara-de la Cruz R, Sánchez-González E et al., First confirmation and characterization of target and non-target site resistance to glyphosate in Palmer amaranth (Amaranthus palmeri) from Mexico. Plant Physiol Biochem 115:212-218 (2017).

36 Jalaludin A, Yu Q, Zoellner P, Beffa R and Powles SB, Characterisation of glufosinate resistance mechanisms in Eleusine indica. Pest Manag Sci 73:1091-1100 (2017).

37 Rojano-Delgado AM, Menendez J and De Prado R, Absorption and penetration of herbicide viewed in metabolism studies: case of glufosinate and imazamox in wheat, in Retention, Uptake, and Translocation of Agrochemical in Plants, ed. by Myung K, Satchivi NM and Kingston CK. ACS Publications, Washington, pp. 159-165 (2014). 